\title{
A rare case of polyorchidism
}

\author{
Ming Ho Liu, ${ }^{1}$ Lokesh Suraparaju² \\ ${ }^{1}$ General Surgery Department, James Paget hospital, Great Yarmouth, Norfolk, UK; \\ 2Urology Department, James Paget hospital, Great Yarmouth, Norfolk, UK
}

Correspondence to Mr Ming Ho Liu, jerrylmh@doctors.org.uk

\section{Summary}

A 28-year-old offshore worker attended accident and emergency department with a tender benign-feeling lump inferior to the left testis. He was previously investigated abroad with an ultrasound scan showing a homogenous mass posterior to the left testis. Subsequent CT was unremarkable. As there was no clinical suspicion of malignancy, a scrotal exploration was performed. During scrotal exploration, the left testicular mass appeared to be a supernumerary testis, which shared the same tunica albuginea. Histology has confirmed the diagnosis. Polyorchidism is an extremely rare congenital anomaly, and can be associated with hydrocele, testicular torsion or rarely malignancy. Leung has classified polyorchidism in four types. This case has been described as type 2; the supernumerary testis shares the epididymis and the vas deferens of the other testis. Treatment can either be conservative or surgical excision. However, if the supernumerary testis is asymptomatic, with negative tumour markers and radiological findings, surgery can be avoided.

\section{BACKGROUND}

This is a rare disorder, with only about 100 cases reported in the literatures. ${ }^{1}$ Good understanding of this anomaly can allow clinician to make better clinical decision.

\section{CASE PRESENTATION}

The patient presented with a left tender small lump inferior to the left testis.

\section{INVESTIGATIONS}

1. Ultrasound showed a homogenous mass posterior to the left testis.

2. CT staging scan did not show any distant metastasis.

\section{DIFFERENTIAL DIAGNOSIS}

Testicular carcinoma. (figure 1).

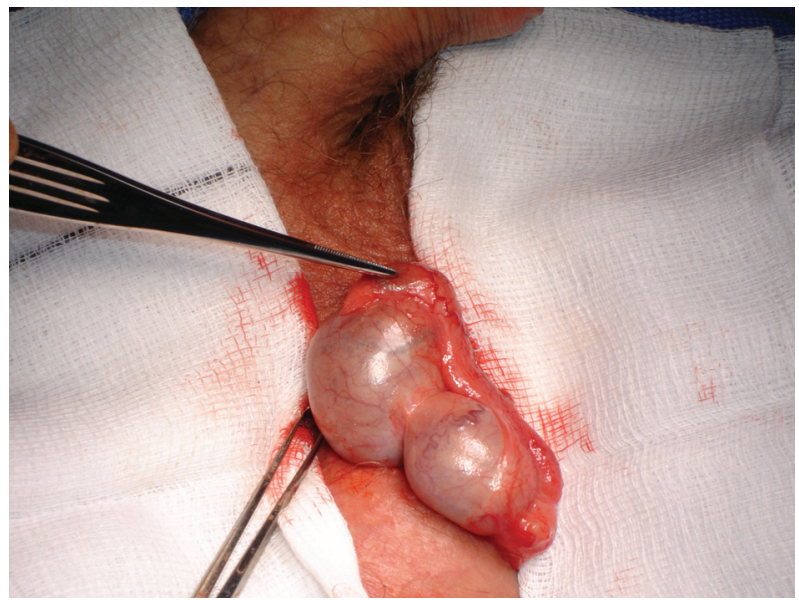

Figure 1 A supernumerary testis, sharing the same tunica albuginea and epididymis.

\section{TREATMENT}

Conservative or surgical excision.

\section{OUTCOME AND FOLLOW-UP}

No further follow-up required if no neoplasia has been confirmed on excisional biopsy.

\section{DISCUSSION}

This is a rare anomaly, with only about 100 cases reported in the literatures. One published case has revealed the diagnosis can be made radiologically, hence conservative management.

\section{Learning points}

- Polyorchidism is a rare anomaly. Four types of variants have been described according to its relation to epididymis and vas deferens.

- Diagnosis can confidently be made with tumour markers and radiological findings.

- Thorough history taking and clinical examination can avoid surgery.

\section{Competing interests None.}

Patient consent Obtained.

\section{REFERENCES}

1. Kharrazi SMH. Rahmani MR, Sakipour M, et al Polyorchidism: A Case Report and Review of Literature. Urol J (Tehran) 2006;3:180-3. 


\section{BMJ Case Reports}

This pdf has been created automatically from the final edited text and images.

Copyright 2012 BMJ Publishing Group. All rights reserved. For permission to reuse any of this content visit http://group.bmj.com/group/rights-licensing/permissions.

BMJ Case Report Fellows may re-use this article for personal use and teaching without any further permission.

Please cite this article as follows (you will need to access the article online to obtain the date of publication).

Liu MH, Suraparaju L. A rare case of polyorchidism.

BMJ Case Reports 2012;10.1136/bcr.02.2012.5937, Published XXX

Become a Fellow of BMJ Case Reports today and you can:

- Submit as many cases as you like

- Enjoy fast sympathetic peer review and rapid publication of accepted articles

- Access all the published articles

- Re-use any of the published material for personal use and teaching without further permission

For information on Institutional Fellowships contact consortiasales@bmjgroup.com

Visit casereports.bmj.com for more articles like this and to become a Fellow

Keep up to date with all published cases by signing up for an alert (all we need is your email address) http://casereports.bmj.com/cgi/alerts/etoc 